\title{
Short term changes in methanol emission and pectin methylesterase activity are not directly affected by light in Lycopersicon esculentum
}

\author{
P. Y. Oikawa ${ }^{1}$, L. Li ${ }^{1}$, M. P. Timko ${ }^{1}$, J. E. Mak ${ }^{2}$, and M. T. Lerdau ${ }^{1,3}$ \\ ${ }^{1}$ Department of Biology, University of Virginia, P.O. Box 400328, Charlottesville, 22904-4328 VA, USA \\ ${ }^{2}$ School of Marine and Atmospheric Sciences, Stony Brook University, Stony Brook, 11794-5000, NY, USA \\ ${ }^{3}$ Department of Environmental Sciences, University of Virginia, P.O. Box 400123, Charlottesville, 22904-4123 VA, USA
}

Received: 5 November 2010 - Published in Biogeosciences Discuss.: 17 January 2011

Revised: 5 April 2011 - Accepted: 8 April 2011 - Published: 29 April 2011

\begin{abstract}
Plants are an important source of atmospheric methanol $(\mathrm{MeOH})$, the second most abundant organic gas after methane. Factors regulating phytogenic $\mathrm{MeOH}$ production are not well constrained in current $\mathrm{MeOH}$ emission models. Previous studies have indicated that light may have a direct influence on $\mathrm{MeOH}$ production. As light is known to regulate cell wall expansion, it was predicted that light would stimulate $\mathrm{MeOH}$ production through the pectin methylesterase (PME) pathway. $\mathrm{MeOH}$ emissions normalized for stomatal conductance $\left(g_{\mathrm{s}}\right)$ did not, however, increase with light over short time scales (20-30 min). After experimentally controlling for $g_{\mathrm{s}}$ and temperature, no light activation of PME activity or $\mathrm{MeOH}$ emission was observed. The results clearly demonstrate that light does not directly influence short-term changes in $\mathrm{MeOH}$ production and emission. Our data suggest that substrate limitation may be important in regulating $\mathrm{MeOH}$ production over short time scales. Future investigation of the long-term impacts of light on $\mathrm{MeOH}$ production may increase understanding of $\mathrm{MeOH}$ emission dynamics at the seasonal time scale.
\end{abstract}

\section{Introduction}

Plants play a dominant role in the global production of methanol $(\mathrm{MeOH})$, an important feature of atmospheric chemistry. Annual global emissions of $\mathrm{MeOH}$ range from $75-280 \mathrm{Tg}$ (teragrams, $10^{12} \mathrm{~g}$ ) $\mathrm{yr}^{-1}$, with plants contributing approximately $75 \%$ of this flux, and the remainder coming from industrial processes, plant decay, biomass burning, and

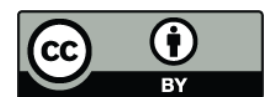

Correspondence to: P. Y. Oikawa (pyo6n@virginia.edu) in situ atmospheric production (Singh et al., 2000; Galbally and Kirstine, 2002; Heikes et al., 2002; Tie et al., 2003; von Kuhlmann et al., 2003a, b; Jacob et al., 2005). In contrast to other volatile organic compounds (VOCs), such as isoprene, which have atmospheric lifetimes on the order of tens of minutes, the lifetime of $\mathrm{MeOH}$ is approximately ten days (Jacob et al., 2005). This long lifetime allows $\mathrm{MeOH}$ to move into the upper troposphere where it can substantially lower hydroxyl radical concentrations as well as increase concentrations of ozone and formaldehyde (Singh et al., 2000, 2001; Tie et al., 2003).

The dominant biosynthetic pathway for $\mathrm{MeOH}$ production in leaves is believed to be the demethylation of pectin by the enzyme pectin methylesterase (PME) (Nemecek-Marshall et al., 1995; Fall and Benson, 1996; Frenkel et al., 1998; Rose and Bennett, 1999; Galbally and Kirstine, 2002; Keppler et al., 2004). Rapidly growing cells export highly methylesterified chains of galacturonic acid (GA; the backbone of pectin) to cell walls (Goldberg et al., 1996). In an ester hydrolysis reaction, GA is demethylated by PME, allowing chains of GA to cross-link and stabilize the cell wall. The methyl groups cleaved from the GA chain form $\mathrm{MeOH}$, which accumulates in the leaf and is released through stomatal openings. As a by-product of this growth-related process, cumulative daily $\mathrm{MeOH}$ flux is known to strongly correlate with leaf expansion (Hüve et al., 2007) and studies have consistently shown that young expanding leaves emit greater amounts of $\mathrm{MeOH}$ than mature leaves (Macdonald and Fall, 1993; Hüve et al., 2007). Although expanding leaves are associated with higher rates of $\mathrm{MeOH}$ production, it is important to note that PMEs are also active in mature tissue (Bordenave and Goldberg, 1994). Plant PMEs are known to belong to large multigene families yielding numerous isoforms of PME, each of which has activities that are regulated by $\mathrm{pH}$ (Bordenave and

Published by Copernicus Publications on behalf of the European Geosciences Union. 
Goldberg, 1994; Goldberg et al., 1996; Willats et al., 2001; Pelloux et al., 2007). The regulation of PME isoforms helps maintain a more flexible cell wall in expanding cells and a rigid cell wall in mature non-expanding cells. Therefore, both mature and immature leaves have active PMEs that produce $\mathrm{MeOH}$ at different rates.

Unlike other VOCs such as monoterpenes and isoprene that are directly linked to photosynthesis, less than $10 \%$ of $\mathrm{MeOH}$ is produced from recently assimilated carbon (Folkers et al., 2008). Although the majority of $\mathrm{MeOH}$ is not immediately derived from light-dependent photosynthesis, light may regulate $\mathrm{MeOH}$ production through the stimulation of leaf expansion. Light is known to lower the $\mathrm{pH}$ of growing cell walls, thereby increasing extensibility of the wall and allowing expansion (Van Volkenburgh, 1999). The process of light-induced apoplastic acidification and cellular growth occurs on the scale of seconds to minutes (Elzenga et al., 1997; Stahlberg and Van Volkenburgh, 1999). Light-induced acidification of the cell wall may influence the activity of certain isoforms of PME, thereby increasing production of $\mathrm{MeOH}$. Additionally, the expansion of the cell wall may increase substrate availability for PME activity, again leading to increased $\mathrm{MeOH}$ production. To our knowledge, the direct response of PME activity and $\mathrm{MeOH}$ production to short-term changes in light has not been measured.

$\mathrm{MeOH}$ emissions are tightly regulated by stomatal conductance $\left(g_{\mathrm{s}}\right)$ (Macdonald and Fall, 1993; NemecekMarshall et al., 1995; Hüve et al., 2007). In order to account for stomatal effects on VOC emission, Niinemets and Reichstein (2003a, b) developed a model incorporating Henry's law constants $\left(H, \mathrm{~Pa} \mathrm{~m}^{3} \mathrm{~mol}^{-1}\right)$, which describe a compound's tendency to partition between gas- and liquidphases. The emission of compounds with large $H$ values, such as isoprene, is not controlled by stomata as the compound will tend to partition and accumulate in the gas-phase, thereby overcoming stomatal closure. Compounds such as $\mathrm{MeOH}$ with low $H$ values are highly soluble in water and are therefore under stomatal control (Niinemets and Reichstein, 2003a, b). Harley et al. (2007) applied the NiinemetsReichstein model to predict $\mathrm{MeOH}$ emissions from several species, assuming temperature-regulated $\mathrm{MeOH}$ production while accounting for changes in $g_{\mathrm{s}}$ and gas- and liquid-phase $\mathrm{MeOH}$ pool sizes. Overestimations of nighttime $\mathrm{MeOH}$ emissions by the model suggested that light may directly influence $\mathrm{MeOH}$ production. The model's inability to account for changes in $\mathrm{MeOH}$ production due to leaf expansion and/or light conditions resulted in significant discrepancies between measurements and model predictions. Similarly, Folkers et al. (2008) could not differentiate the effects of increased $\mathrm{MeOH}$ production and increased $g_{\mathrm{s}}$ on $\mathrm{MeOH}$ emission responses to light. Our understanding of the effects of light on $\mathrm{MeOH}$ is therefore confounded by $\mathrm{MeOH}$ 's dependence on $g_{\mathrm{s}}$.
Light induction of VOC production and emission has been demonstrated for VOCs such as isoprene and monoterpenes. As isoprene and monoterpene biosynthesis are directly linked to photosynthesis, isoprene and non-stored monoterpene emissions are successfully modeled using light as a predictor variable (Loreto et al., 1996a, b; Ciccioli et al., 1997). Isoprene synthase activity is also correlated with light (Lehning et al., 1999). Similarly to previously studied VOCs, investigating the direct influence of light on $\mathrm{MeOH}$ production is an important step in understanding and modeling emission behavior.

In this study, we look at the effects of light on short term changes in $\mathrm{MeOH}$ production and emission in Lycopersicon esculentum under conditions where potential confounding factors such as temperature variation and changes in $g_{\mathrm{s}}$ are limited. In this manner, we can determine the direct relationship between light and $\mathrm{MeOH}$ production.

\section{Materials and methods}

\subsection{Study species}

All Lycopersicon esculentum Mill. individuals were Micro Tom clones, a dwarf variety of tomato (Meissner et al., 1997). L. esculentum was chosen as a model plant due to its rapid growth and high $\mathrm{MeOH}$ emission behavior. Plants were grown in the greenhouse at the University of Virginia in Charlottesville $\left(38^{\circ} \mathrm{N}, 78^{\circ} \mathrm{W}\right)$. Pots were placed in flats filled with one inch of water and were illuminated during a $16 \mathrm{~h}$ period with natural light supplemented with highpressure sodium lamps. Plants were fertilized every two weeks (Scotts 20\% N, 20\% P, 20\% K; Scotts Miracle-Gro Company, Marysville, OH, USA) and kept insect-free using a variety of insecticides. Immature leaves were sampled three weeks past germination and mature leaves six weeks past germination. Leaf size was measured regularly with calipers to ensure that immature leaves were rapidly expanding and mature leaves were fully expanded.

\subsection{Gas exchange measurements}

Leaf-level gas exchange measurements were made with a LI-COR LI-6400 portable gas exchange system (LI-COR Inc., Lincoln, NE, USA). Temperature was regulated within the cuvette using thermoelectric (Peltier) coolers (LI-COR). Photosynthetic photon flux density (PPFD) within the cuvette was controlled with a set of red and blue light-emitting diodes (LI-COR). Depending on the treatment, leaves were exposed to five light levels ranging from low to high light conditions $\left(50,300,650,900,1150 \mu \mathrm{mol} \mathrm{m}^{-2} \mathrm{~s}^{-1}\right)$. Leaf surface area enclosed in the cuvette was measured using a LI-COR Leaf Area Meter (LI-COR Inc., Lincoln, NE, USA). Photosynthetic rates $\left(P_{\mathrm{s}}\right)$ and stomatal conductance $\left(g_{\mathrm{s}}\right)$ are expressed on a per unit leaf area basis $\left(\mu \mathrm{mol} \mathrm{CO}_{2} \mathrm{~m}^{-2} \mathrm{~s}^{-1}\right.$ and $\mathrm{mol} \mathrm{H}_{2} \mathrm{O} \mathrm{m}^{-2} \mathrm{~s}^{-1}$ for $P_{\mathrm{s}}$ and $g_{\mathrm{s}}$, respectively). Relative 
humidity and leaf temperature were also recorded during gas exchange measurements.

\subsection{MeOH emission measurements}

Leaf-level MeOH emissions were quantified with a LI-COR LI-6400 portable gas exchange system (LI-COR Inc., Lincoln, NE, USA) coupled with a proton-transfer-reaction mass spectrometer (High sensitivity PTR-MS; Ionicon Analytik, Innsbruck, Austria). PTR-MS has been described in detail elsewhere (Lindinger et al., 1998). PTR-MS requires no preconcentration or chromatography of VOC. Instead, the air flows directly to the drift tube where VOCs undergo chemical ionization via proton-transfer reaction with $\mathrm{H}_{3} \mathrm{O}^{+}$. Protonated VOCs are then counted by the ion detector and can be measured down to the ppt level. Air exiting the LI-6400 cuvette was routed to the PTR-MS inlet via $1 / 4$ inch Teflon tubing with a $\mathrm{T}$-fitting in order to release extra flow. Flow rates through the cuvette ranged from 150 to $350 \mu \mathrm{mol} \mathrm{s}^{-1}$. Despite typically stable concentrations of $\mathrm{MeOH}$ in ambient air throughout the sampling periods, empty cuvette measurements were coupled with each leaf measurement in order to control for fluctuations in background $\mathrm{MeOH}$. All measurements were taken between 1000 and $1600 \mathrm{~h}$. Leaves were allowed to stabilize at each light level for 20-30 min prior to taking the $\mathrm{MeOH}$ emission measurement. PTR-MS measurements were recorded for 20 cycles for each sample. $\mathrm{MeOH}$ emission rates are expressed on a per unit leaf area basis $\left(\mathrm{nmol} \mathrm{m}{ }^{-2} \mathrm{~s}^{-1}\right)$. MeOH emissions were divided by $g_{\mathrm{s}}$ in order to normalize emission rates for changes in $g_{\mathrm{s}}$. Normalized $\mathrm{MeOH}$ emissions are expressed in $\mathrm{nmol} \mathrm{MeOH}$ per mol of $\mathrm{H}_{2} \mathrm{O}$. Four point calibrations were made regularly throughout the sampling period with dilutions of a gravimetrically prepared $\mathrm{MeOH}$ gas standard provided by the Riemer lab (University of Miami) containing 3 ppmv $\left(3 \mu \mathrm{l}^{-1}\right) \pm 2 \%$ $\mathrm{MeOH}$ in nitrogen gas. Accuracy of $\mathrm{MeOH}$ measurements was estimated to be around 20\% (based on accuracy of calibration measurements) and reproducibility of around $10 \%$.

Three sets of $\mathrm{MeOH}$ emission measurements were conducted. All measurements were taken under steady-state conditions. First, repeated $\mathrm{MeOH}$ emission measurements were conducted on four immature and four mature L. esculentum in which each leaf was exposed to five light levels while keeping temperature constant and allowing $g_{\mathrm{s}}$ to change. Second, repeated $\mathrm{MeOH}$ emission measurements were conducted on five immature and five mature L. esculentum in which each leaf was exposed to five light levels while temperature and $g_{\mathrm{s}}$ were held constant. Using $12 \mathrm{~g}$ LI-COR $\mathrm{CO}_{2}$ cartridges, $g_{\mathrm{s}}$ was kept relatively constant by changing $\mathrm{CO}_{2}$ concentrations within the cuvette. The third set of $\mathrm{MeOH}$ emission measurements were made on leaves that were destructively sampled for enzyme assay analysis directly following the emission measurement (see Sect. 2.4). Emission measurements were collected at five light levels, where a different group of plants $(n=5)$ were sampled at each level totaling 25 immature and 25 mature L. esculentum. Temperature and $g_{\mathrm{s}}$ were held constant.

\subsection{PME enzyme activity assay}

For the third set of $\mathrm{MeOH}$ emission measurements, sampled leaves were excised and frozen in liquid nitrogen directly following the emission measurement. Frozen samples were assayed for PME enzyme activity via a titration technique previously developed for L. esculentum (Anthon and Barrett, 2006). Plant tissue was ground in a mortar and pestle to a fine powder, weighed, and mixed in equal weight with a solution composed of 50\% $2 \mathrm{M} \mathrm{NaCl}$ and $50 \% 10 \mathrm{mM}$ phosphate buffer ( $\mathrm{pH}$ 7.5). Samples were then centrifuged at $8000 \mathrm{~g}$ for $5 \mathrm{~min}$. $25 \mu \mathrm{l}$ of plant supernatant was added to $2.5 \mathrm{ml}$ of pectin solution containing $0.5 \%$ pectin, $0.2 \mathrm{M} \mathrm{NaCl}$, and $0.1 \mathrm{mM}$ phosphate buffer ( $\mathrm{pH} 7.5$ ). Sample solution $\mathrm{pH}$ was adjusted to 7.5 using small amounts of $0.1 \mathrm{M} \mathrm{NaOH}$ (in 1-5 $\mu \mathrm{l})$. Once the solution dropped back down to $\mathrm{pH} 7,1-$ $5 \mu \mathrm{l}$ of $0.1 \mathrm{M} \mathrm{NaOH}$ was added until solution $\mathrm{pH}$ reached 7.3. Time for solution to drop back down to $\mathrm{pH} 7$ was recorded. PME activity is expressed in $\mu \mathrm{molg} \mathrm{fwt}^{-1} \mathrm{~min}^{-1}$ based on the change in $\mathrm{pH}$ for a given amount of fresh tissue over time. Measuring change in $\mathrm{pH}$ over time is a proxy for PME activity and not a direct measurement of enzyme activity, but this change in $\mathrm{pH}$ has been shown to be a highly repeatable proxy for enzyme activity (Anthon and Barrett, 2006). A total of 25 immature and 25 mature plants were assayed for PME enzyme activity.

\subsection{Statistical analysis}

Repeated measurements collected in the first $\mathrm{MeOH}$ emission dataset, where leaves were exposed to five light levels under constant temperature, were analyzed using a mixed model ANOVA (Proc MIXED, SAS 9.1; SAS Institute Inc., Cary, NC, USA). Strength of association between $\mathrm{MeOH}$ emission and PPFD was determined by the significance of the slope of the mixed model. Normalized $\mathrm{MeOH}$ emission data in the first dataset exhibited a decreasing exponential relationship with PPFD and were examined with a generalized linear model with a negative binomial distribution (Proc GENMOD, SAS 9.1; SAS Institute Inc., Cary, NC, USA). The relationship between $g_{\mathrm{S}}$ and PPFD was analyzed using a repeated-measures ANOVA model (Proc GLM, SAS 9.1; SAS Institute Inc., Cary, NC, USA). Linear and non-linear regression lines were fit using SigmaPlot 9.0 (Systat software, Inc. Point Richmond, California, USA).

The second set of repeated $\mathrm{MeOH}$ emission measurements, where leaves were exposed to five light levels under constant temperature and $g_{\mathrm{s}}$, was analyzed using a mixed model ANOVA with $\mathrm{MeOH}$ emission data normalized for $g_{\mathrm{s}}$ (Proc MIXED, SAS 9.1; SAS Institute Inc., Cary, NC, USA). Again, strength of association between normalized $\mathrm{MeOH}$ 
emission and PPFD was determined by the significance of the slope of the mixed model.

In the third set of $\mathrm{MeOH}$ emission measurements, leaves were destructively sampled for PME activity assays under conditions of constant temperature and $g_{\mathrm{s}}$. This third dataset was examined in a two-way MANOVA where the effect of plant type and PPFD on normalized $\mathrm{MeOH}$ emission and PME activity was analyzed (Proc GLM, SAS 9.1; SAS Institute Inc., Cary, NC, USA). Data used in the analysis were Log and square root transformed to meet normality and homogeneity of variance assumptions.

\section{Results}

In the first set of measurements, the relationship between $g_{\mathrm{s}}$ and $\mathrm{MeOH}$ emission was investigated under conditions where light varied and temperature was held constant. $\mathrm{MeOH}$ emission and $g_{\mathrm{s}}$ were measured at five light levels. Stomatal conductance ranged from 0.03$0.17 \mathrm{~mol} \mathrm{H}_{2} \mathrm{O} \mathrm{m}^{-2} \mathrm{~s}^{-1}$ and $0.04-0.22 \mathrm{~mol} \mathrm{H}_{2} \mathrm{O} \mathrm{m}^{-2} \mathrm{~s}^{-1}$ for mature and immature leaves, respectively. Measurements of mature and immature leaves were taken under steadystate conditions at leaf temperature $29 \pm 1{ }^{\circ} \mathrm{C}$, photosynthetic rates $6.7 \pm 4 \mu \mathrm{molCO} \mathrm{CO}_{2} \mathrm{~m}^{-2} \mathrm{~s}^{-1}$ mature and $10 \pm$ $4 \mu \mathrm{mol} \mathrm{CO}_{2} \mathrm{~m}^{-2} \mathrm{~s}^{-1}$ immature, and relative humidity $55 \pm$ $5 \%$ mature and $58 \pm 6 \%$ immature (means $\pm \mathrm{SD}$ ). $\mathrm{MeOH}$ emissions increased with light $(F=16.69 d f=1,15 P=$ 0.001 for mature; $F=110.59 d f=1,15 P<0.0001$ for immature; Fig. 1a). Slopes were positive and significant for both leaf types (slope $=0.0015 t=4.09 P=0.001$ for mature; slope $=0.0044 t=10.52 P<0.0001$ for immature). Light also had an overall significant effect on $g_{\mathrm{s}}$ for both leaf types (Fig. 1b; Wilk's lambda $F=77.78 d f=4,3 P=$ 0.002). When $\mathrm{MeOH}$ flux values were normalized by $g_{\mathrm{s}}$, the influence of light disappeared. The relationship between normalized $\mathrm{MeOH}$ and light was not positive (regression coefficient $=-0.0006, z=-5.53, P<0.0001$ for mature leaves; regression coefficient $=-0.0008, z=-50.20, P<0.0001$ for immature leaves; Fig. 1c). It is important to note that the calculated negative relationship between normalized $\mathrm{MeOH}$ and PPFD is almost certainly an artifact of the normalization of $\mathrm{MeOH}$ and not a biological phenomenon.

As an extension to the first set of measurements, $g_{\mathrm{s}}$ and temperature were experimentally controlled before making repeated $\mathrm{MeOH}$ flux measurements across five light levels. Measurements of mature and immature leaves were taken under steady state conditions at leaf temperature $29 \pm 1{ }^{\circ} \mathrm{C}, g_{\mathrm{s}}$ $0.08 \pm 0.02 \mathrm{~mol} \mathrm{H}_{2} \mathrm{O} \mathrm{m}^{-2} \mathrm{~s}^{-1}$, and relative humidity $58.3 \pm$ $7 \%$ (means $\pm \mathrm{SD}$ ). Although changes in $g_{\mathrm{s}}$ were small across the 5 light levels, $\mathrm{MeOH}$ emissions were normalized for $g_{\mathrm{s}}$ in order to remove all influence of $g_{\mathrm{s}}$ on $\mathrm{MeOH}$ emission. Nonnormalized emission data were also analyzed and found to behave similarly to the normalized emission data (data not shown). Under constant temperature and $g_{\mathrm{s}}$ no significant

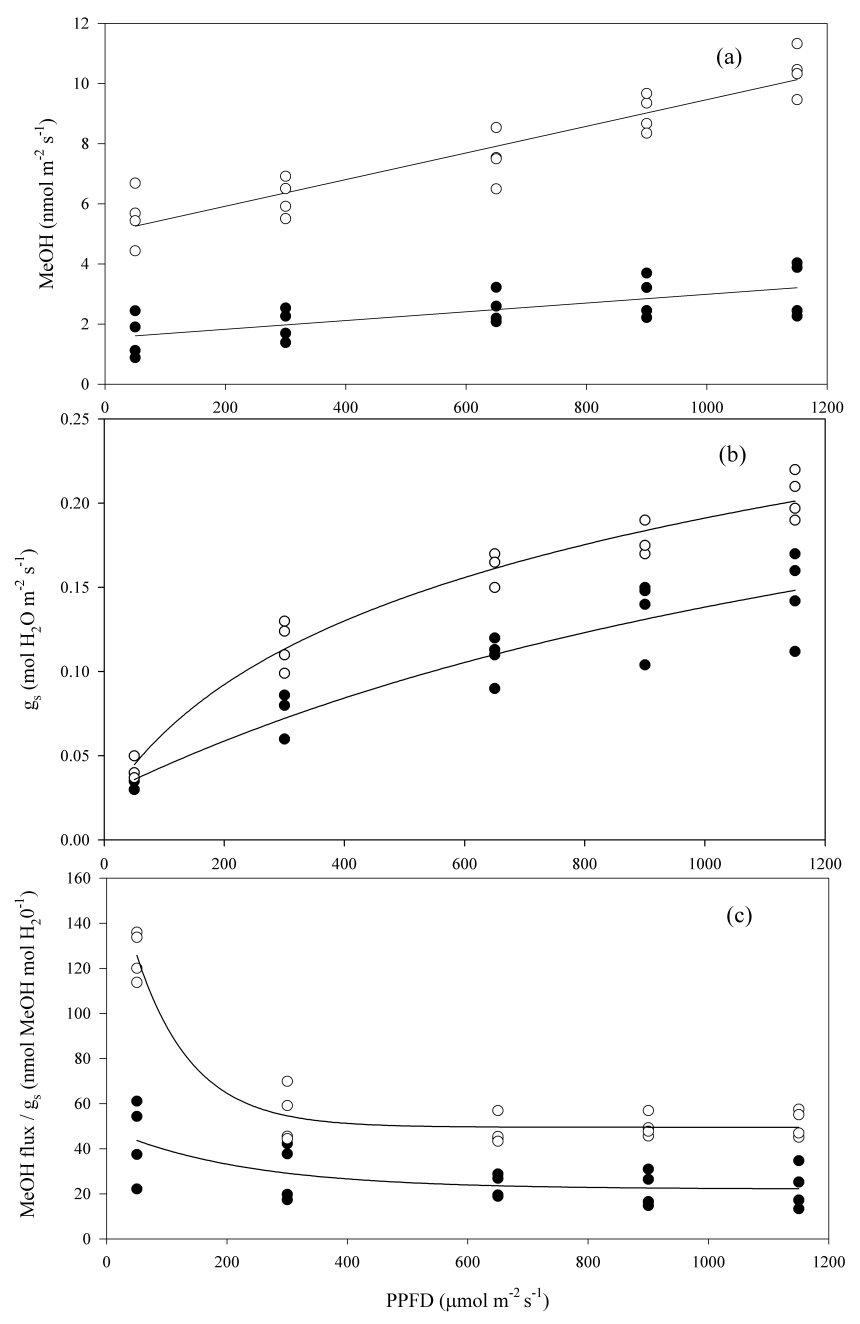

Fig. 1. (a) $\mathrm{MeOH}$ emission, (b) stomatal conductance $\left(g_{\mathrm{s}}\right)$, and (c) $\mathrm{MeOH}$ emission normalized for $g_{\mathrm{s}}$ from mature $(n=4$; black circles) and immature ( $n=4$; open circles) L. esculentum over five light levels at constant temperature $\left(29 \pm 1^{\circ} \mathrm{C}\right) . \mathrm{MeOH}$ emission (slope $=0.0015, t=4.09, P=0.001$ for mature; slope $=0.0044$, $t=10.52, P<0.0001$ for immature $)$ and $g_{\mathrm{s}}(F=112.94 P<$ $0.0001 R^{2}=0.86$ for mature; $F=19.06 P=0.004 R^{2}=0.96$ for immature) significantly increased with PPFD. Normalized $\mathrm{MeOH}$ emissions were negatively associated with PPFD (regression coefficient $=-0.0006, z=-5.53, P<0.0001$ for mature; regression coefficient $=-0.0008, z=-50.20, P<0.0001$ for immature) .

effect of light on normalized $\mathrm{MeOH}$ emissions for mature $(F=2.96 d f=1,19 P=0.10)$ or immature leaves $(F=0.6$ $d f=1,19 P=0.45$ ) was observed (Fig. 2). The results agreed with those from the first set of measurements in that light did not directly stimulate $\mathrm{MeOH}$ emission.

In the third set of $\mathrm{MeOH}$ emission measurements, the direct influence of light on $\mathrm{MeOH}$ production was investigated by assaying PME activity at each light level. Measurements of mature and immature leaves were taken under steady state conditions at leaf temperature $29 \pm 1{ }^{\circ} \mathrm{C}, g_{\mathrm{s}}$ 


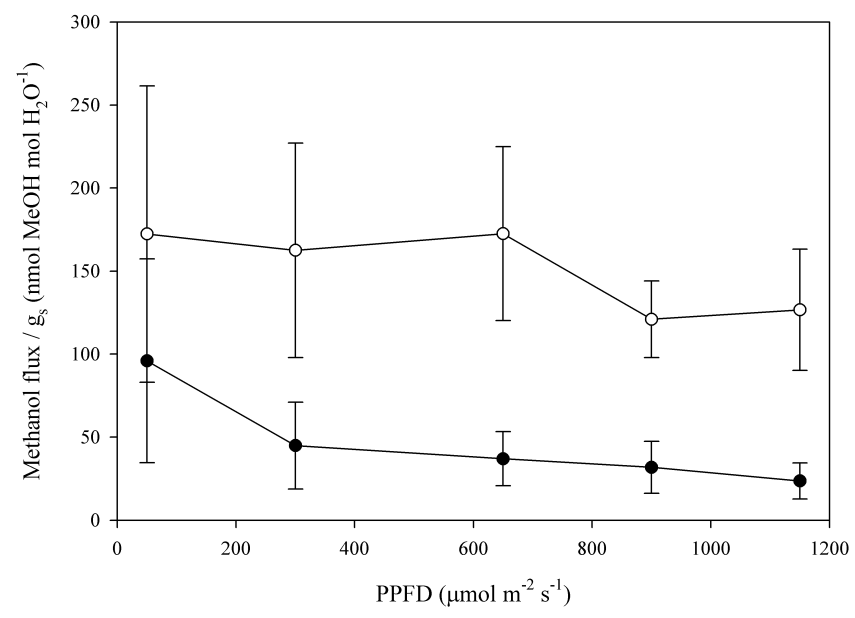

Fig. 2. Average $\mathrm{MeOH}$ flux values normalized for stomatal conductance $\left(g_{\mathrm{s}}\right)$ over five light levels for $n=5$ mature (black circles) and immature (white circles) L. esculentum (each plant was measured $5 \mathrm{x}$; standard error bars shown). PPFD had no significant effect on normalized $\mathrm{MeOH}$ flux for either leaf type $(F=2.96 ; d f=1,19$; $P=0.10$ for mature; $F=0.6 ; d f=1,19 ; P=0.45$ for immature).

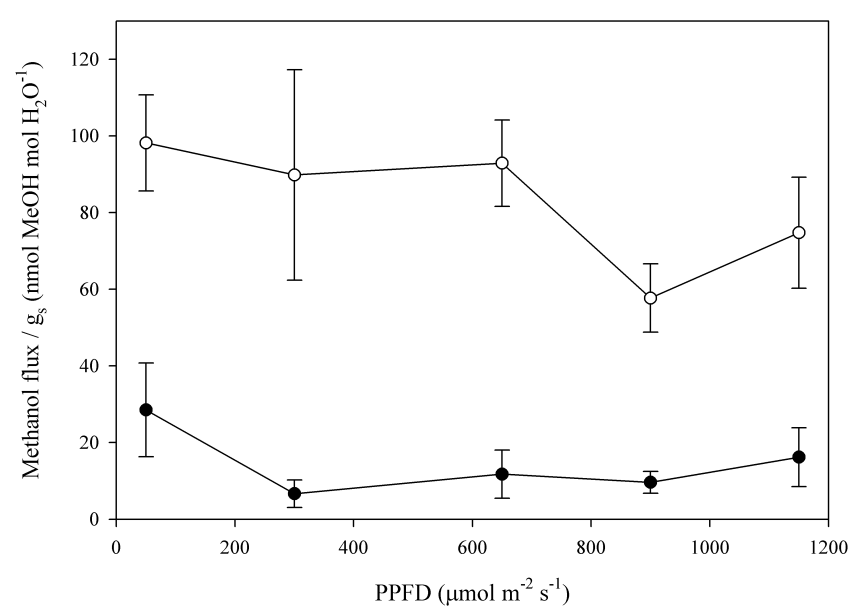

Fig. 3. Average $\mathrm{MeOH}$ flux values normalized for stomatal conductance $\left(g_{\mathrm{s}}\right)$ over five light levels for $n=5$ mature (black circles) and immature (white circles) L. esculentum (standard error bars shown). PPFD had no significant effect on normalized $\mathrm{MeOH}$ flux $(F=0.81$ $d f=4 P=0.53)$. Plant type had a significant effect on normalized $\mathrm{MeOH}$ emission overall $(F=79.43 d f=1 P<0.0001)$.

$0.09 \pm 0.02 \mathrm{~mol} \mathrm{H}_{2} \mathrm{O} \mathrm{m}^{-2} \mathrm{~s}^{-1}$, and relative humidity $54.5 \pm$ $9 \%$ (means $\pm \mathrm{SD}$ ). Immature leaves had significantly greater $\mathrm{MeOH}$ emission and PME activity overall (Wilk's lambda $F=45.47 d f=2,38 P<0.0001)$. Again, $\mathrm{MeOH}$ emissions were normalized for $g_{\mathrm{s}}$ in order to remove all influence of $g_{\mathrm{s}}$ on $\mathrm{MeOH}$ emission. Non-normalized data were analyzed and found to behave similarly to the normalized emission data (data not shown). Light had no significant effect on either PME activity or normalized $\mathrm{MeOH}$ emission under relatively

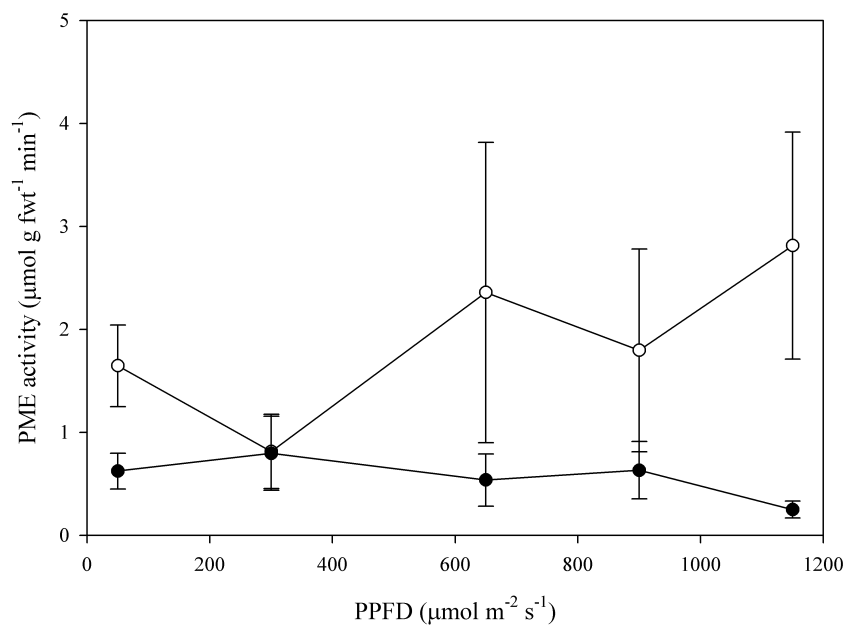

Fig. 4. Average PME activity rates over five light levels for $n=5$ mature (black circles) and immature (white circles) L. esculentum (standard error bars shown). PPFD had no significant effect on enzyme activity $(F=0.40 d f=4 P=0.81)$. Plant type had a significant effect on PME activity overall $(F=14.46 d f=1 P=0.0005)$

constant temperature and $g_{\mathrm{s}}$ (Figs. 3 and 4; Wilk's lambda $F=0.57 d f=8,76 P=0.80$ ). Light was therefore not observed to stimulate $\mathrm{MeOH}$ production through the PME pathway on the time scale of $0-30 \mathrm{~min}$.

\section{Discussion}

Factors regulating $\mathrm{MeOH}$ production in plants are not well constrained in current $\mathrm{MeOH}$ emission models (Galbally and Kirstine, 2002; Karl et al., 2003; Harley et al., 2007). Previous studies have suggested that light directly stimulates $\mathrm{MeOH}$ production (Harley et al., 2007). As light is known to regulate cell wall expansion on the scale of minutes, we predicted that short-term increases in light would stimulate PME activity and $\mathrm{MeOH}$ emission in immature leaves. The results, however, did not bear out these predictions. $\mathrm{MeOH}$ emissions normalized for $g_{\mathrm{s}}$ suggested that changes in $g_{\mathrm{s}}$ were capable of explaining changes in $\mathrm{MeOH}$ emission in response to light. It is important to note that if light influenced $g_{\mathrm{s}}$ and $\mathrm{MeOH}$ emission similarly, then the normalization of $\mathrm{MeOH}$ emission by $g_{\mathrm{s}}$ would have resulted in the removal of the effect of light on $\mathrm{MeOH}$ emission as well. Further experimentation, however, demonstrated that light did not directly influence $\mathrm{MeOH}$ emission as it does $g_{\mathrm{s}}$. Data from the second and third sets of $\mathrm{MeOH}$ emission measurements demonstrated that short-term changes in light do not influence $\mathrm{MeOH}$ emission if $g_{\mathrm{s}}$ and temperature are experimentally controlled. In accord with previous studies, immature leaves had significantly higher $\mathrm{MeOH}$ emission (NemecekMarshall et al., 1995; Hüve et al., 2007), as well as higher PME activity, than mature leaves. Despite being in a rapidly expanding growth phase, PME activity in immature leaves 
was not stimulated by light over time scales of 20-30 min. It is clear that $\mathrm{MeOH}$ emission and production do not behave similarly to other VOCs such as isoprene which are known to increase production and emission in response to short term changes in light. Light does not stimulate PME activity or $\mathrm{MeOH}$ emission in either mature or immature leaves on short time scales.

$\mathrm{MeOH}$ production is regulated not only by PME activity, but also by multiple interacting factors, such as cell wall $\mathrm{pH}$, substrate availability, and PME gene expression (Goldberg et al., 1996; Pelloux et al., 2007). The acidification of the cell wall in response to light-induced growth is known to occur on the scale of seconds to minutes (Elzenga et al., 1997; Stahlberg and Van Volkenburgh, 1999), and we hypothesized that light-induced changes in cell wall $\mathrm{pH}$ and cell expansion would influence $\mathrm{MeOH}$ production. The results, however, suggested that the fast-acting effects of light on the acidification of the cell wall did not significantly alter overall PME activity. It is likely that our PME assay was insensitive to rapidly reversible post-translational changes in PME activity. Additionally, individual PME activity rates may have been stimulated by the light treatment but went undetected, as our assay measured total PME activity. Therefore, changes in PME activity could have occurred, but were not strong and/or prolonged enough to be detected. As PME activity is dependent on cell wall $\mathrm{pH}$, it is surprising that PME activity did not change across a wide spectrum of light intensity. This lack of change in PME activity and $\mathrm{MeOH}$ emission response to light suggests that PME may, at times, be substrate limited. Studies have shown that cell expansion is not immediately accompanied by cell wall synthesis. Rapidly growing cells are known to stretch cell walls thin due to the lack of cell wall components, such as pectin polysaccharides (Refregier et al., 2004). The addition of methylated pectin to the cell wall during 20-30 min of light-induced growth can therefore not be assumed. Although pectin synthesis is generally known to be under developmental control and also induced by mechanical damage, pathogenesis, and cell-cell interactions, understanding of the transcriptional control of cell wall polysaccharides is incomplete (Somerville et al., 2004). In addition to pectin synthesis, the regulation of PME gene expression could also limit $\mathrm{MeOH}$ production. Unfortunately, little is known concerning the gene expression of pectin and PMEs and how they regulate $\mathrm{MeOH}$ production in plants. Despite the lack of knowledge, future research should focus on measuring PME substrate limitation and gene regulation, with the possibility of linking these processes with $\mathrm{MeOH}$ production.

Investigation of long-term changes in $\mathrm{MeOH}$ production and emission in response to light may be valuable for modeling efforts. Factors such as PME activity, PME substrate limitation, and PME gene regulation are not easily incorporated into $\mathrm{MeOH}$ emission models operating over long time scales (hours to days) and greater spatial scales (canopy to regional). Hüve et al. (2007) reported a strong relationship between leaf expansion and $\mathrm{MeOH}$ emission over several days.
Therefore, factors such as light, light-induced growth, and leaf developmental stage may be most relevant for predicting emissions from greater spatial and temporal scales. Previous work has shown that long term effects of light and temperature are important for estimating the production and emission of VOCs such as isoprene and methylbutenol (Harley et al., 1996, 1997; Fuentes and Wang, 1999; Sharkey et al., 1999; Geron et al., 2000; Hanson and Sharkey, 2001; Lehning et al., 2001; Petron et al., 2001; Gray et al., 2005). Incorporating variables that account for light and thermal history have improved VOC model performance, particularly at the seasonal time scale (Gray et al., 2006). The development of a light history term for $\mathrm{MeOH}$ emission models may expand modeling capabilities to the seasonal time scale.

\section{Conclusions}

In order to accurately predict $\mathrm{MeOH}$ emissions, there is a need to understand the factors regulating $\mathrm{MeOH}$ production. This study contributes to that effort as it demonstrates that light does not stimulate PME activity or $\mathrm{MeOH}$ emission over short time scales. Future investigation of PME substrate limitation and gene regulation may improve understanding of the short-term factors regulating $\mathrm{MeOH}$ production. Although light did not regulate $\mathrm{MeOH}$ emission over short time scales, long-term effects of light on $\mathrm{MeOH}$ production and emission may be important for predicting emissions on the seasonal time scale.

Acknowledgements. We thank Federico Brilli, Stephen Chan, Adam Zeilinger, and John Maben for laboratory and technical assistance, and Wendy Crannage for greenhouse assistance. We also thank Gordon Anthon for expert advice and technical assistance.

Edited by: G. Wohlfahrt

\section{References}

Anthon, G. E. and Barrett, D. M.: Characterization of the temperature activation of pectin methylesterase in green beans and tomatoes, J. Agr. Food Chem., 54, 204-211, 2006.

Bordenave, M. and Goldberg, R.: Immobilized and free apoplastic pectinmethylesterases in mung bean hypocotyl, Plant Physiol., 106, 1151-1156, 1994.

Ciccioli, P., Fabozzi, C., Brancaleoni, E., Cecinato, A., Frattoni, M., Loreto, F., Kesselmeier, J., Schafer, L., Bode, K., Torres, L., and Fugit, J. L.: Use of the isoprene algorithm for predicting the monoterpene emission from the Mediterranean holm oak Quercus ilex L.: Performance and limits of this approach, J. Geophys. Res.-Atmos., 102, 23319-23328, 1997.

Elzenga, J. T. M., Staal, M., and Prins, H. B. A.: Calciumcalmodulin signalling is involved in light-induced acidification by epidermal leaf cells of pea, Pisum sativum L, J. Exp. Bot., 48, 2055-2061, doi:10.1093/jxb/48.12.2055, 1997.

Fall, R. and Benson, A. A.: Leaf methanol - The simplest natural product from plants, Trends Plant Sci., 1, 296-301, 1996. 
Folkers, A., Hüve, K., Ammann, C., Dindorf, T., Kesselmeier, J., Kleist, E., Kuhn, U., Uerlings, R., and Wildt, J.: Methanol emissions from deciduous tree species: dependence on temperature and light intensity, Plant Biol., 10, 65-75, doi:10.1111/j.14388677.2007.00012.x, 2008.

Frenkel, C., Peters, J. S., Tieman, D. M., Tiznado, M. E., and Handa, A. K.: Pectin methylesterase regulates methanol and ethanol accumulation in ripening tomato (Lycopersicon esculentum) fruit, J. Biol. Chem., 273, 4293-4295, 1998.

Fuentes, J. D. and Wang, D.: On the seasonality of isoprene emissions from a mixed temperate forest, Ecol. Appl., 9, 1118-1131, 1999.

Galbally, I. E. and Kirstine, W.: The production of methanol by flowering plants and the global cycle of methanol, J. Atmos. Chem., 43, 195-229, 2002.

Geron, C., Guenther, A., Sharkey, T., and Arnts, R. R.: Temporal variability in basal isoprene emission factor, Tree Physiol., 20, 799-805, 2000.

Goldberg, R., Morvan, C., Jauneau, A., and Jarvis, M. C.: Methylesterification, de-esterification and gelation of pectins in the primary cell wall, in: Pectins and Pectinases, edited by: Visser, J. and Voragen, A. G. J., Elsevier Science, Amsterdam, 151-172, 1996.

Gray, D. W., Goldstein, A. H., and Lerdau, M. T.: The influence of light environment on photosynthesis and basal methylbutenol emission from Pinus ponderosa, Plant Cell Environ., 28, 1463$1474,2005$.

Gray, D. W., Goldstein, A. H., and Lerdau, M. T.: Thermal history regulates methylbutenol basal emission rate in Pinus ponderosa, Plant Cell Environ., 29, 1298-1308, 2006.

Hanson, D. T. and Sharkey, T. D.: Effect of growth conditions on isoprene emission and other thermotolerance-enhancing compounds, Plant Cell Environ., 24, 929-936, 2001.

Harley, P., Guenther, A., and Zimmerman, P.: Effects of light, temperature and canopy position on net photosynthesis and isoprene emission from sweetgum (Liquidambar styraciflua) leaves, Tree Physiol., 16, 25-32, 1996.

Harley, P., Guenther, A., and Zimmerman, P.: Environmental controls over isoprene emission in deciduous oak canopies, Tree Physiol., 17, 705-714, 1997.

Harley, P., Greenberg, J., Niinemets, Ü., and Guenther, A.: Environmental controls over methanol emission from leaves, Biogeosciences, 4, 1083-1099, doi:10.5194/bg-4-1083-2007, 2007.

Heikes, B. G., Chang, W. N., Pilson, M. E. Q., Swift, E., Singh, H. B., Guenther, A., Jacob, D. J., Field, B. D., Fall, R., Riemer, D., and Brand, L.: Atmospheric methanol budget and ocean implication, Global Biogeochem. Cy., 16, 1133, doi:10.1029/2002GB001895, 2002.

Hüve, K., Christ, M. M., Kleist, E., Uerlings, R., Niinemets, U., Walter, A., and Wildt, J.: Simultaneous growth and emission measurements demonstrate an interactive control of methanol release by leaf expansion and stomata, J. Exp. Bot., 58, 1783-1793, 2007.

Jacob, D. J., Field, B. D., Li, Q. B., Blake, D. R., de Gouw, J., Warneke, C., Hansel, A., Wisthaler, A., Singh, H. B., and Guenther, A.: Global budget of methanol: Constraints from atmospheric observations, J. Geophys. Res.-Atmos., 110, D08303, doi:10.1029/2004JD005172, 2005.

Karl, T., Guenther, A., Spirig, C., Hansel, A., and Fall, R.: Sea- sonal variation of biogenic VOC emissions above a mixed hardwood forest in northern Michigan, Geophys. Res. Lett., 30, 2186, doi:10.1029/2003GL018432, 2003.

Keppler, F., Kalin, R. M., Harper, D. B., McRoberts, W. C., and Hamilton, J. T. G.: Carbon isotope anomaly in the major plant $\mathrm{C} 1$ pool and its global biogeochemical implications, Biogeosciences, 1, 123-131, doi:10.5194/bg-1-123-2004, 2004.

Lehning, A., Zimmer, I., Steinbrecher, R., Bruggemann, N., and Schnitzler, J. P.: Isoprene synthase activity and its relation to isoprene emission in Quercus robur L-leaves, Plant Cell Environ., 22, 495-504, 1999.

Lehning, A., Zimmer, W., Zimmer, I., and Schnitzler, J. P.: Modeling of annual variations of oak (Quercus robur L.) isoprene synthase activity to predict isoprene emission rates, J. Geophys. Res.-Atmos., 106, 3157-3166, 2001.

Lindinger, W., Hansel, A., and Jordan, A.: Proton-transfer-reaction mass spectrometry (PTR-MS): on-line monitoring of volatile organic compounds at pptv levels, Chem. Soc. Rev., 27, 347-354, 1998.

Loreto, F., Ciccioli, P., Cecinato, A., Brancaleoni, E., Frattoni, M., and Tricoli, D.: Influence of Environmental Factors and Air Composition on the Emission of [alpha]-Pinene from Quercus ilex Leaves, Plant Physiol., 110, 267-275, doi:10.1104/pp.110.1.267, 1996a.

Loreto, F., Ciccioli, P., Cecinato, A., Brancaleoni, E., Frattoni, M., Fabozzi, C., and Tricoli, D.: Evidence of the Photosynthetic Origin of Monoterpenes Emitted by Quercus ilex L. Leaves by ${ }^{13} \mathrm{C}$ Labeling, Plant Physiol., 110, 1317-1322, doi:10.1104/pp.110.4.1317, 1996b.

Macdonald, R. C. and Fall, R.: Detection of substantial emissions of methanol from plants to the atmosphere, Atmos. Environ. AGen., 27, 1709-1713, 1993.

Meissner, R., Jacobson, Y., Melamed, S., Levyatuv, S., Shalev, G. Ashri, A., Elkind, Y., and Levy, A.: A new model system for tomato genetics, Plant J., 12, 1465-1472, 1997.

Nemecek-Marshall, M., Macdonald, R. C., Franzen, F. J., Wojciechowski, C. L., and Fall, R.: Methanol emission from leaves - enzymatic detection of gas-phase methanol and relation of methanol fluxes to stomatal conductance and leaf development, Plant Physiol., 108, 1359-1368, 1995.

Niinemets, U. and Reichstein, M.: Controls on the emission of plant volatiles through stomata: Differential sensitivity of emission rates to stomatal closure explained, J. Geophys. Res.-Atmos., 108(17), 4208, doi:10.1029/2002jd002620, 2003a.

Niinemets, U. and Reichstein, M.: Controls on the emission of plant volatiles through stomata: A sensitivity analysis, J. Geophys Res.-Atmos., 108, 4211, doi:10.1029/2002JD002626, 2003b.

Pelloux, J., Rusterucci, C., and Mellerowicz, E. J.: New insights into pectin methylesterase structure and function, Trends Plant Sci., 12, 267-277, doi:10.1016/j.tplants.2007.04.001, 2007.

Petron, G., Harley, P., Greenberg, J., and Guenther, A.: Seasonal temperature variations influence isoprene emission, Geophys. Res. Lett., 28, 1707-1710, 2001.

Refregier, G., Pelletier, S., Jaillard, D., and Hofte, H.: Interaction between wall deposition and cell elongation in dark-grown hypocotyl cells in Arabidopsis, Plant Physiol., 135, 959-968, doi:10.1104/pp.104.038711, 2004.

Rose, J. K. C. and Bennett, A. B.: Cooperative disassembly of the cellulose-xyloglucan network of plant cell walls: parallels 
between cell expansion and fruit ripening, Trends Plant Sci., 4, 176-183, 1999.

Sharkey, T. D., Singsaas, E. L., Lerdau, M. T., and Geron, C. D.: Weather effects on isoprene emission capacity and applications in emissions algorithms, Ecol. Appl., 9, 1132-1137, 1999.

Singh, H., Chen, Y., Tabazadeh, A., Fukui, Y., Bey, I., Yantosca, R., Jacob, D., Arnold, F., Wohlfrom, K., Atlas, E., Flocke, F., Blake, D., Blake, N., Heikes, B., Snow, J., Talbot, R., Gregory, G., Sachse, G., Vay, S., and Kondo, Y.: Distribution and fate of selected oxygenated organic species in the troposphere and lower stratosphere over the Atlantic, J. Geophys. Res.-Atmos., 105, 3795-3805, 2000.

Singh, H., Chen, Y., Staudt, A., Jacob, D., Blake, D., Heikes, B., and Snow, J.: Evidence from the Pacific troposphere for large global sources of oxygenated organic compounds, Nature, 410, 1078-1081, 2001.

Somerville, C., Bauer, S., Brininstool, G., Facette, M., Hamann, T., Milne, J., Osborne, E., Paredez, A., Persson, S., Raab, T., Vorwerk, S., and Youngs, H.: Toward a systems approach to understanding plant cell walls, Science, 306, 2206-2211, doi:10.1126/science.1102765, 2004.
Stahlberg, R. and Van Volkenburgh, E.: The effect of light on membrane potential, apoplastic $\mathrm{pH}$ and cell expansion in leaves of Pisum sativum L. var. Argenteum., Planta, 208, 188-195, 1999.

Tie, X., Guenther, A., and Holland, E.: Biogenic methanol and its impacts on tropospheric oxidants, Geophys. Res. Lett., 30, 1881, doi:10.1029/2003GL017167, 2003.

Van Volkenburgh, E.: Leaf expansion - an integrating plant behaviour, Plant Cell Environ., 22, 1463-1473, 1999.

von Kuhlmann, R., Lawrence, M. G., Crutzen, P. J., and Rasch, P. J.: A model for studies of tropospheric ozone and nonmethane hydrocarbons: Model description and ozone results, J. Geophys. Res.-Atmos., 108(22), 4294, doi:10.1029/2002jd002893, 2003a. von Kuhlmann, R., Lawrence, M. G., Crutzen, P. J., and Rasch, P. J.: A model for studies of tropospheric ozone and nonmethane hydrocarbons: Model evaluation of ozone-related species, J. Geophys. Res.-Atmos., 108(26), 4729, doi:10.1029/2002jd003348, 2003 b.

Willats, W. G. T., McCartney, L., Mackie, W., and Knox, J. P.: Pectin: cell biology and prospects for functional analysis, Plant Mol. Biol., 47, 9-27, 2001. 